\title{
ANALISIS DESKRIPTIF HASIL BELAJAR PEMBELAJARAN TATAP MUKA DAN PEMBELAJARAN DARING MENURUT GAYA BELAJAR MAHASISWA
}

\author{
Anthony Anggrawan \\ Universitas Bumigora (Kontak: +6282340002666, anthony,anggrawan17@gmail.com)
}

\begin{abstract}
ABSTRAK
Setiap institusi perguran tinggi memiliki pilihan model pembelajaran yang akan diselenggarakan, yaitu model pembelajaran tatap muka, daring dan campuran. Model pembelajaran tatap muka dan daring memiliki kelebihan dan sekaligus kekurangan dalam mendukung gaya belajar mahasiswa. Gaya belajar mahasiswa bukan hanya mewakili apa yang disukai oleh mahasiswa dalam pembelajaran, tetapi juga mempengaruhi hasil belajar mahasiswa. Sehingga tidak mengherankan, sampai sekarang ini masih terjadi silang pendapat dalam capaian pembelajaran, pembelajaran tatap muka ataukah pembelajaran daring yang memberikan hasil yang lebih baik. Penelitian ini memberikan solusi jawaban pada pembelajaran bahasa Inggris, apakah pembelajaran tatap muka ataukah pembelajaran daring yang lebih unggul dalam capaian pembelajaran kognitif menurut gaya belajar mahasiswa. Hasil analisis deskriptif pada studi ini menyimpulkan bahwa mahasiswa dengan gaya belajar auditori dan visual yang dibelajarkan dengan model pembelajaran daring memiliki rata-rata nilai hasil belajar yang lebih unggul dibandingkan dengan mahasiswa yang dibelajarkan dengan model pembelajaran tatap muka; tidak ada perbedaan nilai rata-rata hasil belajar mahasiswa kinestetik antara mahasiswa yang dibelajarkan dengan pembelajaran tatap muka dengan mahasiswa yang dibelajarkan dengan pembelajaran daring; dan secara umum hasil analsis deskriptif menunjukkan bahwa mahasiswa pembelajaran daring lebih berhasil dalam capaian hasil belajar dibandingkan dengan mahasiswa pembelajaran tatap muka pada pembelajaran bahasa Inggris.
\end{abstract}

Kata kunci: model pembelajaran, tatap muka, daring, hasil belajar, bahasa Inggris

\section{ABSTRACT}

Each higher education institution has a choice of learning models to be held, namely face-to-face learning, online learning, and blended learning. Face-to-face and online learning models have advantages and disadvantages in supporting student learning styles. Student learning styles not only represent what students like in learning, but also affect student learning outcomes. So it is not surprising, until now there is still a crossing of opinion in the achievement of learning, face-to-face learning or online learning that provides better results. This study provides an answer solution to learning English, whether face-to-face learning or online learning that is superior in cognitive learning outcomes according to student learning styles. The results of the descriptive analysis in this study concluded that students with auditory and visual learning styles taught with online learning models had higher average learning outcomes compared to students taught with face-to-face learning models; there is no difference in the average value of kinesthetic student learning outcomes between students who are taught by face-to-face learning with students who are taught by online learning; and in general the results of descriptive analysis show that online learning students are more successful in achieving learning outcomes compared to face-to-face learning students in learning English.

Keywords: learning model, face to face, online, learning outcomes, english language 


\section{PENDAHULUAN}

Saat ini ada berbagai model pembelajaran yang dapat diselenggarakan oleh perguruan tinggi, yaitu pembelajaran tradisional tatap muka, pembelajaran daring, dan pembelajaran campuran (yaitu pembelajaran kombinasi antara pembelajaran tatap muka dan pembelajaran daring). Sehingga dengan sendirinya, setiap institusi perguruan tinggi memiliki pilihan model pembelajaran yang akan diterapkan sebagai model pembelajaran diperguruan tingginya masing-masing. Umumnya, setiap intitusi perguruan tinggi dan/atau dosen pengajar memiliki alasan dan pertimbangan sendiri untuk memilih model pembelajaran mana yang paling cocok dari setiap mata kuliah yang ada untuk diselenggarakan pada pembelajaran mahasiswa. Faktor utama yang seharusnya dipertimbangan dalam menetapkan pilihan model pembelajaran yang digunakan pada setiap perguruan tinggi adalah faktor pencapaian (keberhasilan) hasil belajar, selain faktor lingkungan belajar dan biaya operasional. Yang menjadi faktor pertama dalam pemilihan model pembelajaran umumnya adalah faktor pencapaian hasil belajar, yakni model pembelajaran yang dianggap cocok dan bisa menghantarkan hasil belajar kognitif yang minimal berhasil baik, atau yang bisa meningkatkan kualifikasi kognitif lulusan. Faktor lingkungan belajar, juga dipertimbangkan dalam pemilihan model pembelajaran pada mata kuliah tertentu di perguruan tinggi karena jika lingkungan belajar yang cocok bagi mahaiswa tertentu tidak didukung oleh model pembelajaran yang digunakan saat mempelajari mata kuliah yang dipelajari mahasiswa, maka akan menimbulkan kesulitan belajar bagi mahasiswa yang belajar, yang pada akhirnuya berakibat pada kegagalan dalam mencapai hasil belajar yang baik pada mahasiswa bersangkutan. Sebagai contoh, katakan model pembelajaran yang digunakan adalah model pembelajaran tatap muka, jika lokasi kampus pada lokasi yang ramai bunyi klakson mobil, atau suara gaduh lainnya, maka akan sangat mengganggu lingkungan belajar mahasiswa yang memiliki gaya belajar selain visual. Faktor lain yang biasanya dipertimbangkan dalam pemilihan odel pembelajaran adalah faktor biaya operasional pembelajaran. Secara jangka pendek dan jangka panjang, model pembelajaran tatap memrlukan biaya yang relatif cukup besar dalam penyelengaraaan pembelajaran. Sedangkan model pembelajaran daring pada awal penyelenggaraan perlu biaya relatif cukup besar, namun selanjutnya memerlukan biaya yang lebih ringan, setidaknya dalam biaya sumber daya manusia dan infrastruktur pemeliharaan serta pengadaan sarana dan prasarana kelas/kampus.

Pembelajaran tatap muka adalah pembelajaran kelas yang mengandalkan pada kehadiran dosen pengajar untuk mengajar dikelas. Pada pembelajaran tatap muka mahasiswa terlibat dalam komunikasi verbal spontan pada lingkungan fisik permanen [1]. Menurut Norman (2016), salah satu masalah dalam pembelajaran tatap muka tradisional adalah memerlukan biaya perkuliahan yang lebih besar terlebih lagi pada perguruan tinggi ternama [2]. Namun hal yang menguntungkan dalam pembelajran tatap muka adalah hasil survei menunjukkan bahwa sebagian besar mahasiswa tidak terganggu dalam menghadiri kuliah tatap muka dan melihat kehadiran dalam pelajaran tatap muka berpengaruh pada psikologis, emosional dan menyerap materi pembelajaran dan solusi atas masalah pembelajaran [3]. Kehadiran mahasiswa pada pembelajaran kelas tatap muka tidak menjadi perhatian utama dari institusi perguruan tinggi, tetapi yang menjadi perhatian utama adalah lebih pada keterkaitan kehadiran mahasiswa tersebut dengan kepuasan mahasiswa itu sendiri dalam mengikuti pembelajaran yang dipelajari [3]. Hal ini berarti, lingkungan 
belajar yang mendukung kepuasan pembelajaran mahasiswa atas model pembelajaran tatap mukalah yang menjadi hal yang utama dalam pembelajaran tatap muka, dan dengan sendirinya jika lingkungan belajar cocok bagi mahasiswa akan menimbulkan semangat (meningkatkan motivasi) belajar mahasiswa yang akhirnya akan berimbas pada hasil belajar yang lebih baik.

Para ahli setuju bahwa pada pembelajaran kelas tatap muka terjadi interaksi yang bermakna dan nyata antara mahasiswa dengan mahasiswa dan antara mahasiswa dengan dosen pengajar yang tidak dapat digantikan atau dijumpai pada pembelajaran daring [1].

Jenis aktivitas belajar yang dijumpai di pembelajaran tradisional tatap muka adalah: ceramah, latihan yang dikerjakan di kelas dan dikerjakan dirumah, diskusi, pembacaan teks pelajaran, tugas tim dan individu. Sedangkan aktivitas belajar yang dijumpai pada pembelajaran daring adalah: pembelajaran mandiri dari informasi yang diperoleh dari dokumen daring dan database, latihan daring, tugas daring, pencarian materi pembelajaran individual, berbagi pengetahuan secara daring dengan mahasiswa lain, konferensi video, dan diskusi interaktif [4].

Model pembelajaran daring memungkinkan mahasiswa untuk mengatur lokasi, kapan belajar dan kecepatan belajar, yang tidak dijumpai pada metode pembelajaran tradisional tatap muka.

Smaldino, Lowther, dan Russell (2008) mengatakan, model pembelajaran daring mampu mewujudkan fungsi pembelajaran yang efektif [5]. Bahkan menurut Machmes dan Asher sebagaimana yang dikutip oleh Roblyer \& Doering (2010), belajar interaktif dua arah pada daring adalah lebih efektif daripada pembelajaran tradisional [6].

Sekalipun terdapat beberapa institusi perguruan tinggi tetap menentang pembelajaran daring, namun beberapa institusi perguruan tinggi lainnya telah menerima pembelajaran daring sebagai bagian kegiatan pembelajaran [7]. Untungnya saat ini, kemajuan sarana prasarana teknologi yang diperlukan dalam menyelenggarakan pembelajaran daring yang efektif telah berkembang dengan sangat pesat dari waktu kewaktu [8]. Gambar 1. memperlihatkan kondisi perkembangan pembelajaran mandiri secara daring dan kondi perkembangan pembelajaran tatap muka [9].

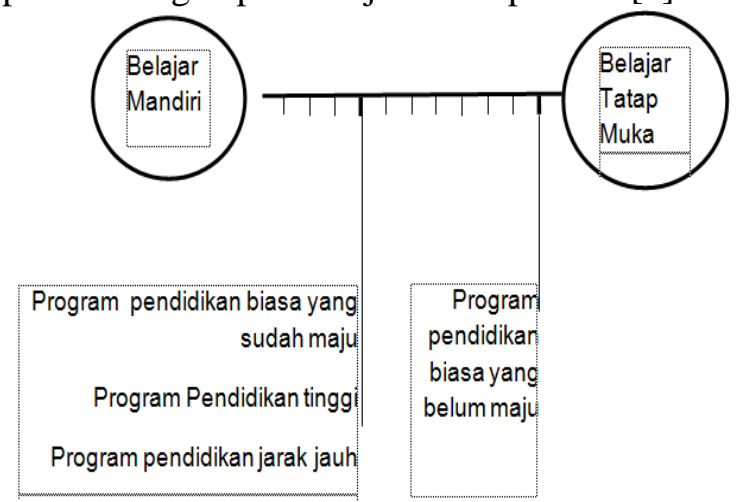

Gambar 1. Kondisi Perkembangan Pembelajaran

Tatap muka dan Pembelaajran Mandiri daring

Pembelajaran tatap muka berorientasi pada dosen pengajar (Lecturer Oriented) dan lingkungan pembelajaran di kontruksi oleh dosen pengajar. Sedangkan pembelajaran daring berorientasi pada mahasiswa (Student oriented), dan mahasiswa mengkontruksi lingkungan pembelajaran [10].

Merujuk pada fakta yang telah dikemukan diatas, tampak masing-masing model pembelajaran baik model pembelajaran tatap muka maupun pembelajaran daring memiliki kelebihan dibalik kekurangan yang ada. Sehingga tidak mengherankan, sampai sekarang ini terkait dengan capaian hasil pembelajaran, apakah pembelajaran tatap muka ataukah pembelajaran daring yang lebih baik, masih terjadi silang pendapat. Pendapat diatas diperkuat dengan pendapat Simonson, Smaldino, Albright, \& Zvacek (2012), bahwa belum ada proses yang jelas dan diverifikasi untuk menentukan apakah belajar tatap muka, belajar daring, atau belajar dengan model campuran dari keduanya adalah yang terbaik [10]. Demikian juga pada perguruan tinggi Universitas Bumigora belum ada kepastian 
terkait dengan pembelajaran bahasa Inggris apakah masih tetap akan mengandalkan model pembelajaran tatap muka, ataukah mencoba model pembelajaran daring maupun model campuran tatap muka dan daring, dengan alasan belum adanya hasil penelitian ilmiah yang telah dilakukan.

Dengan demikian penelitian terkait perbandingan hasil belajar pembelajaran tatap muka dan pembelajaran daring mana yang lebih unggul capaian pembelajaran penting bagi universitas Bumigora dan juga perlu bagi dunia pendidikan di perguruan tinggi yang mengajarkan pembelajaran mata kuliah bahasa Inggris.

Analisis deskriptif pada penelitian ini akan mengkaji secara deskriptif hasil belajar mahasiswa yang dibelajarkan dengan pembelajaran tatap muka dan dibandingkan dengan hasil belajar mahasiswa yang dibelajarkan dengan pembelajaran daring. Hasil penelitian ini memberikan jawaban apakah pada pembelajaran bahasa Inggris sebaiknya tetap bertahan dengan pembelajaran tatap muka karena memang lebih unggul capaian hasil belajarnya, ataukah sebaiknya beralih ke pembelajaran daring.

Gaya belajar mempresentasikan sesuatu yang lebih disukai mahasiswa dalam pembelajaran. Ada 3 macam gaya belajar mahasiswa yaitu gaya belajar visual, auditori dan kinestetik. Penelitian terdahulu menyimpulkan bahwa hasil belajar mahasiswa dipengaruhi oleh gaya belajar mahasiswa, terutama apabila lingkungan belajar mengakomodasi gaya belajar mahasiswa [11].

Daring learning mewujudkan pembelajaran "ubiquitous" bagi mahasiswa [12], sehingga pembelajaran daring mendukung gaya belajar mahasiswa yang menyukai lingkungan belajar sesuai kesukaannya dan juga mendukung gaya belajar mahasiswa yang meyukai belajar mandiri maupun kolaborasi. Mahasiswa yang memiliki gaya belajar spesifik yang dominan lebih sulit dalam menyerap pembelajaran dibandingkan dengan mahasiswa yang memiliki gaya belajar spesifik yang kurang dominan [13]. Mahasiswa dengan gaya belajar auditori menyukai pembelajaran dalam bentuk suara, misalnya pembelajaran ceramah dan diskusi [14]. Mahasiswa dengan gaya belajar visual menyukai pembelajaran dengan media yang berwujud tulisan, gambar, diagram, dan grafik dan media sejenisnya [13][14][15]. Sedangkan mahasiswa dengan gaya belajar kinestetik menyukai pembelajaran berwujud kegiatan atau praktik [14].

Dari penjelasan terkait gaya belajar, terlihat bahwa gaya belajar mahasiswa mempengaruhi hasil belajar mahasiswa. Bagaimana hasil belajar mahasiswa berdasarkan gaya belajar mahasiswa, akan dianalisis secara deskriptif dalam penelitian ini.

Bahasa Inggris merupakan salah satu mata kuliah pada semester awal pada program studi Ilmu Komputer di Universitas Bumigora di Mataram. Pembelajaran bahasa Inggris dikampus Universitas Bumigora selama ini dan sampai sekarang masih mengandalkan pembelajaran tatap muka.

Faktor penting dalam pembelajaran bahasa adalah sikap mahasiswa dalam pembelajaran. Ada tiga komponen sikap mahasiswa dalam pembelajaran yaitu kognitif, afektif, dan perilaku [16]. Hasil penelitian yang dilakukan oleh Mantiri (2015) menunjukkan bahwa kombinasi dari komponen kognitif, afektif, dan perilaku merupakan cerminan dari gaya belajar mahasiswa [16]. Beberapa hasil penelitian sebelumnya menegaskan bahwa ada keterkaitan erat antara gaya belajar mahasiswa dan model pembelajaran dalam pembelajaran bahasa asing [17]. Hasil penelitian terdahulu lainnya menegaskan bahwa untuk meningkatkan hasil belajar bahasa Inggris menuntut penggunaan teknologi pembelajaran secara efektif [18]. Sehingga, penelitian hasil belajar pembelajaran bahasa Inggris berdasarkan gaya belajar mahasiswa pada studi ini menjadi sangat relevan karena akan mengungkapkan bagaimana keterkaitan gaya belajar dan model 
pembelajaran tatap muka dan daring pada hasil belajar pembelajaran bahasa inggris.

\section{METODOLOGI}

Pada penelitian ini, terdapat dua kelas atau kelompok mahasiswa yang masing-masing terdiri dari 50 mahasiswa tiap kelompok yang dibelajarkan dengan model pembelajaran yang berbeda. Kelompok mahasiswa pertama dibelajarkan pembelajaran bahasa Inggris dengan pembelajaran tatap muka, sedangkan kelompok mahasiswa kedua dibelajarkan pembelajaran bahasa Inggris dengan pembelajaran daring. Mahasiswa pembelajaran daring belajar secara mandiri dan/atau kolaboratif dengan sesama mahasiswa secara daring. Modul pembelajaran daring mata kuliah bahasa Inggris telah disiapkan pada komputer server yang bisa diakses kapan saja, dari mana saja oleh mahasiswa secara unsynchronous. Modul pembelajaran daring mata kuliah bahasa Inggris berisi materi pelajaran yang merupakan duplikat murni dari RPS (Rencana Pembelajaran Semester) permbelajaran tatap muka yang selama ini merupakan RPS yang digunakan dalam pembelajaran tatap muka pembelajaran bahasa Inggris di Universitas Bumigora. Module pembelajaran daring mata kuliah bahasa Inggris yang digunakan oleh kelompok mahasiswa untuk belajar secara daring pada penelitian ini telah melewati evaluasi formatif, sehingga telah memenuhi persyaratan sebagai modul pembelajaran daring yang layak untuk mencapai tujuan pembelajaran. Hasil evaluasi formatif dari modul pembelajaran daring yang digunakan pada penelitian ini telah di presentasikan pada seminar internasional ICoCSIM (International Conference on Computational Science and Information Management), bulan Maret 2019 di Lombok, Mataram [19].

Kedua kelompok mahasiswa diambil secara acak dari populasi mahasiswa baru semester pertama tahun angkatan 2017/2018 di Universitas Bumigora (sebelumnya bernama STMIK Bumigora) di Mataram. Kuesioner VARK didistribusikan untuk mengetahui gaya belajar mahasiswa di kedua kelas pembelajaran. VARK merupakan instrumen standar yang sudah teruji validasi dan reliabilitasnya. Hasil belajar mahasiswa yang mendapat pembelajaran tatap muka dan daring dianalisis deskriftif dengan menggunakan bantuan program aplikasi statistik SPSS.

Modul pembelajaran daring yang digunakan dalam penelitian merupakan duplikasi dari Rencana Pembelajaran Semester (RPS) pembelajaran tatap muka yang selama ini sudah digunakan dalam pembelajaran tatap muka di Universitas Bumigora, sebagaimana ditunjukkan pada gambar 2 .



Gambar 2. Perwujudan Modul pembelajaran daring

\section{HASIL DAN PEMBAHASAN}

Table 1. Ringkasan Hasil Analisis Deskriptif Hasil Pembelajaran Bahasa Inggris

\begin{tabular}{|c|c|c|c|c|}
\hline \multicolumn{2}{|c|}{ Gaya Belajar Pembelajaran } & $\begin{array}{c}\text { Daring } \\
\text { (A1) }\end{array}$ & $\begin{array}{l}\text { Tatap } \\
\text { Muka } \\
\text { (A2) }\end{array}$ & $\begin{array}{l}\text { Jumla } \\
\mathrm{h} \\
\text { Baris }\end{array}$ \\
\hline \multirow[t]{6}{*}{$\begin{array}{l}\text { Auditori } \\
\text { (B1) }\end{array}$} & $\begin{array}{l}\text { Jumlah } \\
\text { data }\end{array}$ & 22 & 24 & 46 \\
\hline & Rata-rata & 58,2 & 52.41 & 55,20 \\
\hline & Median & 57,5 & 52 & 56 \\
\hline & Std Deviasi & 4,07 & 4,21 & 5.04 \\
\hline & Minimum & 52 & 42 & 42 \\
\hline & Maksimum & 74 & 60 & 74 \\
\hline \multirow[t]{6}{*}{$\begin{array}{l}\text { Visual } \\
\text { (B2) }\end{array}$} & $\begin{array}{l}\text { Jumlah } \\
\text { data }\end{array}$ & 18 & 15 & 33 \\
\hline & Rata-rata & 65 & 57,93 & 61.79 \\
\hline & Median & 66 & 58 & 60 \\
\hline & Std Deviasi & 4,61 & 4,25 & 5.66 \\
\hline & Minimum & 58 & 48 & 48 \\
\hline & Maksimum & 74 & 67 & 74 \\
\hline \multirow[t]{5}{*}{$\begin{array}{l}\text { Kinestetik } \\
\text { (B3) }\end{array}$} & $\begin{array}{l}\text { Jumlah } \\
\text { data }\end{array}$ & 10 & 8 & 18 \\
\hline & Rata-rata & 50,3 & 50,75 & 50,5 \\
\hline & Median & 51 & 52 & 51 \\
\hline & Std Deviasi & 4,13 & 4,77 & 4,3 \\
\hline & Minimum & 42 & 40 & 40 \\
\hline
\end{tabular}




\begin{tabular}{|c|c|c|c|c|}
\hline \multicolumn{2}{|c|}{ Gaya Belajar Pembelajaran } & $\begin{array}{c}\text { Daring } \\
\text { (A1) }\end{array}$ & $\begin{array}{l}\text { Tatap } \\
\text { Muka } \\
\text { (A2) }\end{array}$ & $\begin{array}{l}\text { Jumla } \\
\mathrm{h} \\
\text { Baris }\end{array}$ \\
\hline & Maksimum & 56 & 56 & 56 \\
\hline \multirow[t]{6}{*}{$\begin{array}{l}\text { Jumlah } \\
\text { Kolom }\end{array}$} & $\begin{array}{l}\text { Jumlah } \\
\text { data }\end{array}$ & 50 & 47 & 97 \\
\hline & Rata-rata & 59,08 & 53.89 & 56.57 \\
\hline & Median & 58 & 54 & 56 \\
\hline & Std Deviasi & 6.82 & 5,1 & 6.56 \\
\hline & Minimum & 42 & 40 & 40 \\
\hline & Maksimum & 74 & 67 & 74 \\
\hline
\end{tabular}

Analisis deskriptif hasil belajar mahasiswa yang menerima pembelajaran kelas tatap muka dan mahasiswa yang mendapat pembelajaran daring diproses untuk mendapatkan distribusi hasil deskriptif pembelajaran di kedua kelas menurut gaya belajar mahasiswa (visual, auditori dan kinestetik) sebagaimana yang disajikan pada tabel 1 .

Secara umum, di kedua kelas belajar, mahasiswa yang memiliki gaya belajar auditori (46) lebih banyak daripada mahasiswa yang memiliki gaya belajar visual (33) dan gaya belajar kinestetik (18). Nilai rata-rata hasil belajar mahasiswa yang diajarkan oleh pembelajaran daring $(59,08)$ lebih tinggi daripada nilai belajar rata-rata siswa yang diajarkan oleh pembelajaran tatap muka $(53,89)$. Sehingga dapat disimpulkan bahwa mahasiswa yang dibelajarkan dengan pembelajaran daring secara deskriptif lebih unggul dalam hasil belajar dengan mahasiswa yang dibelajarkan dengan pembelajran tatap muka.

\subsection{Deskripsi hasil belajar pembelajaran daring (A1)}

Jumlah mahasiswa yang diajarkan dengan pembelajaran daring sebanyak 50 mahasiswa dengan gaya belajar auditori, visual dan kinestetik. Skor maksimum adalah 74, skor minimum adalah 42, standar deviasi adalah 2,82, median adalah 58 dan skor rata-rata hasil belajar adalah 59,08.

\subsection{Deskripsi hasil belajar pembelajaran tatap muka (A2)}

Jumlah mahasiswa yang diajarkan dengan pembelajaran tatap muka sebanyak 47 mahasiswa. Skor maksimum 67, skor minimum 40, standar deviasi 5,1, median 54 dan skor ratarata hasil pembelajaran 53,89 .

\subsection{Deskripsi data hasil belajar mahasiswa yang memiliki gaya belajar auditori (B1)}

Jumlah mahasiswa yang memiliki gaya belajar auditori adalah 46 mahasiswa. Skor maksimum 74, skor minimum 42, standar deviasi 5,04, median 56 dan skor rata-rata hasil belajar 55,20.

\subsection{Deskripsi data hasil belajar mahasiswa yang memiliki Gaya Belajar visual (B2) \\ Jumlah mahasiswa yang memiliki gaya belajar visual adalah 33 mahasiswa. Skor maksimum 74 , skor minimum 48 , standar deviasi 5,04, median 60 dan skor rata-rata hasil belajar 61,79 .}

\subsection{Deskripsi data hasil belajar mahasiswa yang memiliki Gaya Belajar kinestetik (B3)}

Jumlah mahasiswa yang memiliki gaya belajar kinestetik adalah 18 mahasiswa. Skor maksimum 56, skor minimum 40, standar deviasi 5,04, median 60 dan skor rata-rata hasil belajar 50,5.

\subsection{Deskripsi hasil belajar mahasiswa yang diajarkan oleh pembelajaran daring dan memiliki gaya belajar auditori (A1B1)}

Jumlah mahasiswa yang memiliki gaya belajar auditori yang dipelajari oleh pembelajaran daring adalah 22 mahasiswa. Skor maksimum 74, skor minimum 52, standar deviasi 4,3, median 51 dan skor rata-rata hasil pembelajaran 58,2 .

\subsection{Deskripsi hasil belajar mahasiswa yang} diajarkan dengan pembelajaran tatap muka dan memiliki gaya belajar auditori (A2B1)

Jumlah mahasiswa yang memiliki gaya belajar auditori yang diajarkan oleh pembelajaran tatap muka adalah 24 mahasiswa. Skor maksimum 60, skor minimum 42, standar deviasi 4,21, median 52 dan skor rata-rata hasil pembelajaran 52,41. 


\subsection{Deskripsi hasil belajar mahasiswa yang diajarkan oleh pembelajaran daring dan memiliki gaya belajar visual (A1B2)}

Jumlah mahasiswa yang memiliki gaya belajar visual yang diajarkan oleh pembelajaran daring adalah 18 mahasiswa. Skor maksimum 74, skor minimum 58, standar deviasi 4,61, median 66 dan skor rata-rata hasil belajar 65 .

\subsection{Deskripsi hasil belajar mahasiswa yang diajarkan dengan pembelajaran tatap muka dan memiliki gaya belajar visual (A2B2)}

Jumlah mahasiswa yang memiliki gaya belajar visual yang diajarkan dengan pembelajaran tatap muka adalah 15 mahasiswa. Skor maksimum 67, skor minimum 48, standar deviasi 4,25, median 58 dan skor rata-rata hasil belajar 57,93 .

\subsection{Deskripsi hasil belajar mahasiswa yang diajarkan oleh pembelajaran daring dan memiliki gaya belajar kinestetik (A1B3)}

Jumlah mahasiswa yang memiliki gaya belajar kinestetik yang diajarkan oleh pembelajaran daring adalah 10 mahasiswa. Skor maksimum 56, skor minimum 42, standar deviasi 4,13, median 51 dan skor rata-rata hasil pembelajaran 50,3.

\subsection{Deskripsi hasil belajar mahasiswa yang} diajarkan dengan pembelajaran tatap muka dan memiliki gaya belajar kinestetik (A2B3)

Jumlah mahasiswa yang memiliki gaya belajar kinestetik yang diajarkan dengan pembelajaran tatap muka sebanyak 8 mahasiswa. Skor maksimum 56, skor minimum 40, standar deviasi 4,77, median 52 dan skor rata-rata hasil pembelajaran 50,75 .

Dari penjabaran deskripsi terkait hasil pembelajaran antara mahasiswa yang mendapatkan pembelajaran tatap muka dan mahasiswa yang mendapatkan pembelajaran daring menyimpulkan bahwa mahasiswa dengan gaya belajar auditori dan visual yang dibelajarkan dengan model pembelajaran daring memiliki rata-rata nilai hasil belajar yang lebih unggul dibandingkan dengan mahasiswa yang dibelajarkan dengan model pembelajaran tatap muka; dan tidak ditemukan adanya perbedaan nilai rata-rata hasil belajar mahasiswa kinestetik antara mahasiswa yang dibelajarkan dengan pembelajaran tatap muka dengan mahasiswa yang dibelajarkan dengan pembelajaran daring.

\section{SIMPULAN DAN SARAN}

Hasil belajar mahasiswa yang memiliki gaya belajar auditori dan visual yang dibelajarkan dengan model pembelajaran daring memiliki nilai rata-rata hasil belajar yang lebih baik dari mahasiswa yang dibelajarkan dengan model pembelajaran tatap muka. Tidak ada perbedaan nilai ratarata hasil belajar mahasiswa yang memiliki gaya belajar kinestetik antara kelompok mahasiswa yang dibelajarkan dengan pembelajaran tatap muka dengan kelompok mahasiswa yang dibelajarkan dengan pembelajaran daring.

Perlu ada pernilitian lebih lanjut terhadap penelitian pembelajaran tatap muka maupun pembelajaran daring pada mata kuliah yang sama maupun mata kuliah yang lainnya, dan juga dengan model pembelajaran lain seperti pembelajaran tatap muka maupun daring berbasis masalah, kolaboratif, dan model lainnya.

\section{UCAPAN TERIMA KASIH}

Penulis menyampaikan terima kasih kepada pimpinan Rektorat Universitas Bumigora, ketua Lembaga Penelitian Universitas Bumigora, dan juga kepada dekan fakultas teknik dan Kesehatan Universitas Bumigora di Mataram Indonesia, karena bantuannya sehingga studi ini bisa diselesaikan.

\section{REFERENSI}

[1] C. M. Tang and L. Y. Chaw, "Readyness for Blended Learning: Understanding Attitude of University Students," Int. J. Cyber Soc. Educ., vol. 6, no. 2, pp. 79 
100, 2013.

[2] S. Norman, "Traditional Education and Advantages of Online Learning," 2016.

[3] S. Alam and L. Jackson, "A Case Study: Are Traditional Face-To-Face Lectures Still Relevant When Teaching Engineering Courses ?," vol. 3, no. 4, pp. 9-16, 2013.

[4] J. Schreurs, "E-Blended Learning for Distance Learners," in International Conference WWW/Internet, 2003, pp. 1204-1209.

[5] S. E. Smaldino, D. L. Lowther, and J. D. Russell, Instructional Technology and Media for Learning. Canada: Pearson, 2008.

[6] A. H. Roblyer, M. D and Doering, Integrating Educational Technology in Teaching. Boston: Pearson, 2013.

[7] A. Liu, G. Hodgson, and W. Lord, "Innovation in Construction Education: The Role of Culture in E-learning," Archit. Eng. Des. Manag., vol. 6, pp. 91103, 2010.

[8] M. K. Clark, Tom and Barbour, "Online, Blended, and Distance Education in Schools: Building Successful Program." Stylus Publishing, United States of America, 2015.

[9] M. A. Suparman, Educational Technology in distance learning. Jakarta, Indonesia: Open University, Indonesian Ministry of Education and Culture, 2014.

[10] M. Simonson, S. Smaldino, M. Albright, and S. Zvacek, Teaching and Learning at a Distance: Foundation of Distance Education. 2012.

[11] G. D. Eudoxie, "Learning Styles among Students in an Advanced Soil Management Class : Impact on Students, Performance," pp. 137-144, 2011.

[12] A. J. A and nd M. Molenda, Educational Technology. New York: Taylor \& Francis Group, LLC., 2008.

[13] S. Psycharis, E. Botsari, and G. Chatzarakis, "Examining the Effects of Learning Styles, Epistemic Beliefs and the Computational Experiment Methodology On Learners' Performance Using the Easy Java," J. Educ. Comput. Res., vol. 51, no. 1, pp. 91-118, 2014.
Styles Preferences and Academic," vol. 09, no. 02, pp. 479-492, 2016.

[15] Ž. Pekić, "The Impact of Felder's Learning Styles Index on Motivation and Adoption of Information Throught ELearning," vol. 6, no. December, pp. 93100, 2016.

[16] O. Mantiri, "Key to Language Learning Success," J. Arts Humanit., pp. 14-19, 2015.

[17] R. Sparks and L. Ganschow, "Aptitude for learning a foreign language," pp. 90112, 2001.

[18] S. Suppasetseree and N. K. Dennis, "Challenges and Issues Implementing and Integrating Educational Technology for Teaching and Learning English at a Local University in Thailand," Int. J. Arts Sci., vol. 4, no. 24, pp. 135-142, 2011.

[19] A. Anggrawan, A. H. Yassi, and C. Satria, "Instructional Development and Formative Evaluation of English grammar for Online Learning," in the Third International Conference on Computational Science and Information Management, 2019, pp. 1-5.

[14] W. B. Rhouma, "Perceptual Learning 